\title{
Combined effect of treatment with intrauterine antimicrobials and GnRH on the conception rate of repeat breeder Frieswal cattle
}

\author{
TX Seena ${ }_{2}^{1}$ SN Archana ${ }^{2}$, Amitha Thomas ${ }^{3}$, Justin Davis ${ }^{4}$ and Metilda Joseph ${ }^{5}$
}

Received: 21 December 2020 / Accepted: 04 April 2021 / Published online: 27 July 2021

(C) Indian Dairy Association (India) 2021

\begin{abstract}
Repeat breeding in cattle inversely affects the profitability of dairy industry by decreasing conception rate. Selected 18 repeat breeder cows reared under ideal farm conditions and divided them into three groups of six animals each viz., group I, II and III with four primiparous cows and two second parity cows in each group. The cows in group I were treated with intrauterine preparation containing aqueous solution of povidone iodine $(5 \% \mathrm{w} / \mathrm{v})$ and metronidazole $(1 \% \mathrm{w} / \mathrm{v})$ (Utrodin IU), followed by uterine lavage with $120 \mathrm{~mL}$ of normal saline and inseminated them in oestrus after skipping the first heat. The animals in group II were treated with an IM injection of buserelin acetate (Gynarich) post AI. The cows in group III were treated with both Utrodin IU and Gynarich post AI. The conception rate observed in group I, II and III were $66.67 \%$ ( $4 / 6$ cows), $66.67 \%$ ( $4 / 6$ cows) and $83.33 \%$ (5/6 cows), respectively. The results of the study indicated that combined use of intrauterine preparation containing metronidazole and povidone iodine, along with $\mathrm{GnRH}$ was more satisfactory than their individual use in improving the conception rate of repeat breeder Frieswal cattle under farm conditions in Kerala.
\end{abstract}

Keywords: GnRH analogue, Metronidazole, Povidone iodine, Ideal farm conditions, Kerala

\footnotetext{
${ }^{1}$ Cattle Breeding Farm, Thumburmuzhy, Konnakkuzhy. P.O. Kerala Veterinary and Animal Sciences, University, Kerala-680721, India

${ }^{2}$ Department of Veterinary Public Health and Epidemiology, College of Veterinary and Animal Science, Hassan-573202, Karnataka, India

${ }^{3}$ Department of Livestock Production Management, College of Veterinary and Animal Sciences, Mannuthy P.O, Kerala-680651, India

TX Seena $(\square)$

Cattle Breeding Farm, Thumburmuzhy, Konnakkuzhy. P.O. Kerala Veterinary and Animal Sciences, University, Kerala-680721, India Email:drseenatx@gmail.com; Mob.9074765638
}

Repeat breeding is the major cause of decreased profitability of the dairy industry by reducing the conception rate (Ahmadi and Dehghan, 2007) and increasing the treatment cost. Since it is caused by multiple factors, different treatment strategies have been developed for improving the conception rate. One of the best method is intrauterine treatment with antimicrobials, which restores a healthy uterine environment and improves the fertility (Kumar et al. 2014; Mido et al. 2016). As $40.1 \%$ of the total causes of repeat breeding in cattle is hormonal insufficiency (Maurer and Echternkamp, 1985), the hormonal therapy is the most effective method to treat repeat breeders (Tiwari et al. 2019). The administration of GnRH or its analogue, post AI can increase the conception rate in repeat breeder cows (Asaduzzaman et al. 2016; Kaim et al. 2003; Lee et al. 1983). A study was conducted to evaluate the combined effect of intrauterine treatment with metronidazole and povidone iodine and IM administration of GnRH post AI on the conception rate of repeat breeder Frieswal cows of different parity, under ideal farm conditions in Kerala.

Eighteen repeat breeder Frieswal cows reared under ideal farm conditions in Kerala were selected and divided them in to three groups of six animals each viz., group I, II and III. Each group consists of four primiparous cows and two cows in second parity. They were in good health and condition and vaccinated them against prevalent diseases and let loose for three hours of exercise on alternate days. Dewormed the cows with albendazole @ the dose rate of $10 \mathrm{mg} / \mathrm{kg}$ body weight orally. The cows were machine milked twice a day and having a milk yield of 3000-4000 kg/ lactation. They were fed with chopped Hybrid Napier green grass and concentrate feed containing $20 \%$ crude protein and required amount of minerals and vitamins manufactured by School of Applied Animal Nutrition and Feed Technology, College of Veterinary and Animal Sciences, Mannuthy as per the standards set by POP (2016).

The cows in group I were treated with intrauterine preparation containing $60 \mathrm{~mL}$ aqueous solution of povidone iodine I.P. $5 \% \mathrm{w} /$ $\mathrm{v}$ (available iodine $0.5 \% \mathrm{w} / \mathrm{v}$ ) and metronidazole I.P. $(1 \% \mathrm{w} / \mathrm{v})$ (Utrodin IU Liquid, Nectar Lab Associates, Calicut, Kerala, India), (a) the dose rate of 30-60 $\mathrm{mL}$ depending on the size and capacity of the uterus. The intrauterine treatment in all animals was followed by $120 \mathrm{~mL}$ normal saline lavage to clear out the uterine 
Table 1 The conception rate in treatment groups

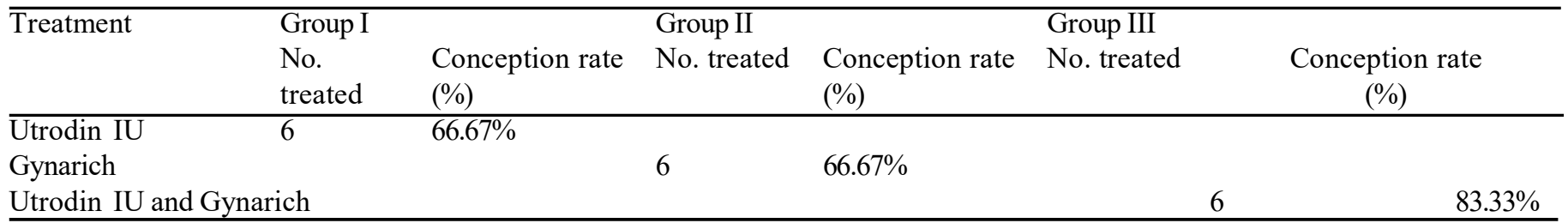

secretions and inseminated them 12 hours after the onset of oestrus with Frieswal bull semen by rectovaginal technique after skipping the first heat. The animals in group II were inseminated 12 hours after the onset of oestrus with Frieswal bull semen by rectovaginal technique and given an IM injection of $2.5 \mathrm{~mL}$ Gynarich, which contains a GnRH analogue, busereline acetate 4 $\mu \mathrm{g} / \mathrm{mL}$ (manufactured by Intas Pharmaceuticals Ltd, India) immediately after the insemination. The cows in group III received both intrauterine treatment with Utrodin IU Liquid and Gynarich injection post AI.

All the experimental animals were examined on 60-75 days after insemination by rectal palpation technique to confirm pregnancy. Conception rate in all the groups were documented and the efficacy of the treatment was evaluated on the basis of posttreatment conception rate.

The results of the present study are given in Table 1. Highest conception rate of $83.33 \%$ was observed in group III after treatment with Utrodin IU and Gynarich, whereas the conception rate $(66.67 \%)$ noticed in both group I and group II were equal in the study. A higher conception rate of $53.33 \%$ (Jana, 2010) and $83.33 \%$ (Butani et al. 2016) was reported after treatment with 5\% povidone iodine and $1 \%$ metronidazole in repeat breeder cows. Increase in conception rate by $21.5 \%$ (Asaduzzaman et al. 2016), 63.2\% (Kaim et al. 2003) and 25\% (Lee et al. 1983), was documented in repeat breeder cows after GnRH post AI treatment. The improvement in fertility after Utrodin IU and Gynarich treatment in the present study can be due to two reasons. Firstly, intrauterine treatment with povidone iodine and metronidazole would have restored the healthy uterine environment and improved the fertility by reducing the aerobic and obligately anaerobic bacterial count in the bovine uterus (Bogaard et al.1992; Koujan et al. 1996; Mido et al. 2016).

Secondly, the positive effect of GnRH on improving the ovulation rate (Yaniz et al. 2004), and preventing delayed ovulation (Hamid and Kamruzzaman, 2017). Since the preovulatory surge of LH normally occurs about 6 hours after onset of estrus (Schams et al. 1977), treatment with GnRH at the time of AI may have induced a secondary surge of LH before or after the spontaneous preovulatory surge of LH. This additional LH may be associated with improvement in conception rate. Administration of single dose of GnRH can increase CL formation (Kaim et al. 2003) and rise in plasma progesterone concentration (Mehni et al. 2012) which is due to hypertrophy and hyperplasia of the luteal cells (Kaim et al. 2003).

\section{Conclusions}

Based on the present study, it is concluded that combined effect of treatment with intrauterine preparation containing metronidazole and povidone iodine and GnRH was more satisfactory than using them separately in improving the conception rate of repeat breeder Frieswal cattle under ideal farm conditions in kerala.

\section{References}

Ahmadi MR, Dehghan SA (2007) Evaluation of the treatment of repeat breeder dairy cows with uterine lavage plus PGF-2 alpha, with and without cephapirin. Turkish J Vet Anim Sci 31: 125-129.

Asaduzzaman KM, Bhuiyan MMU, Rahman MM, Bhattacharjee J (2016) Prevalence of repeat breeding and its effective treatment in cows at selected areas of Bangladesh. Bangladesh J Vet Med 14: 183

Bogaard AE, Hazen MJ, Kriele CP (1992) Rationale for treatment of retained placenta in cows with neomycin and metronidazole. Vet Rec 130: 349-350

Butani MG, Dhami AJ, Shah RG, Sarvaiya NP, Killedar A (2016) Management of repeat breeding in buffaloes under field conditions using hormonal and antibacterial therapies. Buffalo Bulletin 35: 8391

Hamid SA, Kamruzzaman SM (2017) Effects of GnRH on conception rate at the time of artificial insemination in crossbred dairy cows. Int J Anim Sci Technol 1: 19-34

Jana D (2010) Clinical trial of metricare IU on the treatment of repeat breeding cows. North-East Veterinarian 10: 13-14

Kaim M, Bloch A, Wolfenson D, Braw-Tal R, Rosenberg M, Voet H, Folman Y (2003) Effects of GnRH administered to cows at the onset of estrus on timing of ovulation, endocrine responses, and conception. J Dairy Sci 86: 2012-2021

Koujan A, Eissa HM, Hussein MA, Ayoub MM, Afiefy MM (1996) Therapeutic efficacy of povidone-iodine (Betadine) and dichloroxylenol (Septocid) in Holstein cows affected with endometritis and/or cervicitis. Acta Vet Hung 44: 111-119

Kumar M, Pant SS, Ram R, Kumar S, Gupta PK (2014) Therapeutic efficacy of levofloxacin along with vitamin $\mathrm{E}$ for the management of repeat breeding syndrome in cow under field condition. Inter J Vet Sci $3: 155-157$

Lee CN, Maurice RL, Pennington JA, Hoffman WF (1983) Efficacy of gonadotropin-releasing hormone administered at the time of artificial insemination of heifers and postpartum and repeat breeder dairy cows. Am J Vet Res 44:2160-2163

Maurer RR, Echternkamp SE (1985) Causes and influences of repeat breeding in beef cattle. Beef Research Program Progress Report 2: 49-51 
Mehni SB, Shabankareh HK, Kazemi- Bonchenari M, Eghbali M (2012) The comparison of treating Holstein dairy cows with progesterone, CIDR and GnRH after insemination on serum progesterone and pregnancy rates. Reprod Domest Anim 47: 131-134.

Mido S, Murata N, Rawy MS, Kitahara G, Osawa T (2016) Effects of intrauterine infusion of povidone-iodine on endometrial cytology and bacteriology in dairy cows with clinical endometritis. J Vet Med Sci 78: 551-556

POP (2016) Package of Practices Recommendations, Directorate of Entrepreneurship, Kerala Veterinary and Animal Sciences University, Pookode, India. p32-35
Schams D, Shellenberger E, Hoffman B, Karg H (1977) The oestrous cycle of the cow: hormonal parameters and time relationships concerning oestrus, ovulation, and electrical resistance of the vaginal mucus. Acta Endocrinol 86: 180-192

Tiwari I, Shah R, Kaphle K, Gautam M (2019) Treatment approach of different hormonal therapy for repeat breeding dairy animals in Nepal. Arch Vet Sci Med 2: 028-040

Yaniz JL, Murugavel K, Lopez-Gatius F (2004) Recent developments in oestrous synchronization of postpartum dairy cows with and without ovarian disorders. Reprodu Domest Anim 39: 86-93 